\title{
The Migration of Women from Northern China: A Gender-oriented Choice?
}

\section{Florence Lévy}

Translator. Will Thornely

\section{Q OpenEdition \\ Journals}

\section{Electronic version}

URL: http://journals.openedition.org/chinaperspectives/6032

DOI: 10.4000/chinaperspectives.6032

ISSN: 1996-4617

\section{Publisher}

Centre d'étude français sur la Chine contemporaine

\section{Printed version}

Date of publication: 7 December 2012

Number of pages: $43-51$

ISSN: 2070-3449

\section{Electronic reference}

Florence Lévy, « The Migration of Women from Northern China: A Gender-oriented Choice? », China Perspectives [Online], 2012/4 | 2012, Online since 01 December 2015, connection on 28 October 2019. URL : http://journals.openedition.org/chinaperspectives/6032 ; DOI : 10.4000/chinaperspectives.6032 


\title{
The Migration of Women from
}

\section{Northern China: A Gender-oriented}

Choice?

\author{
FLORENCE LÉVY
}

\begin{abstract}
Since the late 1990s, a little-known wave of Chinese migrants has been making its way to France. Coming from regions with no tradition of international mobility, it differs from classic migratory flows in that it consists mainly of urban middle-class women in their forties who are affected by the reform policy. Drawing on the point of view of these female migrants regarding developments in the job market, their economic resources, and changes in family relations, this article examines the transformations in social norms and gender roles that affected these people before their departure. It considers whether these developments have had an impact beyond China's borders, and whether they may have influenced the gender configuration of this migratory flow making its way to Europe.
\end{abstract}

KEYWORDS: migrations, women, northern China, gender norms, gender roles, xiagang, divorce, single parenthood.

S ince the late 1990s, France has been experiencing a new wave of Chinese migrants, which, unlike older migratory flows, is coming from the cities of northern China. Relatively little is known about this recent flow, however, because it quite often takes place illegally and consequently does not appear in official data.(1) Even so, in the 2000s it was estimated to amount to tens of thousands of people, at a time when the number of Chinese nationals or people of Chinese origin in France was thought to be between 200,000 and 300,000 . (2)

Despite its minority status within the Chinese diaspora in France, ${ }^{(3)}$ this recent migration is especially interesting because it differs both from the traditional profile of economic migrants and from that of the majority of Chinese people in France, who originate from the Wenzhou region in southern China. ${ }^{(4)}$ One of its characteristic features is that it is made up mostly of women whose socioeconomic situation was fairly good before they decided to embark on their migratory project. ${ }^{(5)}$

This article, which draws on the analysis of ethnographical interviews carried out in Paris between 2004 and 2010, (6) focuses in particular on the factors that prompted the interviewed women to leave their native country. In view of this mainly female migratory flow, we will look at whether this gender imbalance tells us anything about the transformations in social and gender norms that specifically affected northern Chinese city dwellers in their forties in the 1990s. By looking at women's life trajectories, we will try to gain an understanding of how their migratory project was shaped and what role their experience of gender social relations and gender discrimination played in their decision to migrate. By revealing difficulties that are not necessarily exclusive to women but which bring into play social expectations and resources that often differ between the sexes, this article will attempt to show the impact of gender social relations in China on the configuration of this flow and on the meaning given to migration by the migrants, both male and female.

\section{An atypical female migration: The theoretical approach}

The international migratory flows from China to Europe have become greatly diversified over recent decades, with a significant contingent of migrants now coming from northern China, especially to France. (7) Some of the characteristics of this new migratory flow challenge certain traditional representations that depict economic migrants from developing countries

1. Chloé Cattelain et al., Les modalités d'entrée des ressortissants chinois en France, Paris, Direction de la Population et des Migrations (DPM), 2002; Yun Gao et Véronique Poisson, Le trafic et l'exploitation des immigrants chinois en France, Geneva, Bureau international du travail, 2005.

2. See Yun Gao and Véronique Poisson, Le trafic et l'exploitation..., op. cit.

3. There are few quantitative studies on this flow, but the findings are corroborative and suggest that migrants from the north make up $25-34 \%$ of all recent migrants from China; these studies were carried out in China between 2000 and 2004 on samples of 149 to 15,232 Chinese migrants. See Yun Gao and Véronique Poisson, Le trafic et l'exploitation..., op. cit., p. 29.

4. For more information on migrants from the Wenzhou region of Zhejiang Province, among others see: Jean-Philippe Béja and Wang Chunguang, "Un 'village du Zhejiang' à Paris ?," Hommes et migrations, No. 1220, July-August 1999; Véronique Poisson, Franchir les frontières : le cas des Chinois du Zhejiang en diaspora, Paris, EHESS, doctoral thesis, 2004; Véronique Poisson (ed.), "Chinois de France," Hommes et migrations, No. 1254, 2005, p. 153; Chloé Cattelain et al., Les modalités d'entrée des ressortissants chinois en France, Paris, Direction de la Population et des Migrations (DPM), 2002; Carine Pina-Guerassimoff et al., La circulation des nouveaux migrants économiques chinois en France et en Europe, Paris, ministère de l'Emploi, de la Solidarité et de la Cohésion sociale, DREES/MIRE, 2002.

5. Florence Lévy, "Les migrations des femmes du Nord de la Chine : l'exil, alternative à une situation de déclin ?", Colloque Mobilités au féminin, 15-19 November 2005, Tangier, Laboratoire Méditerranéen de Sociologie, Maison Méditerranéenne des Sciences de l'Homme, CNRS, http://lames.mmsh.univ-aix.fr/Papers/Levy.pdf (consulted on 22 September 2012).

6. These interviews were carried out as part of my dual doctoral thesis at the "Centre d'études sur la Chine moderne et contemporaine" (CECMC) (Research centre on modern and contemporary China) of the "École des hautes études en sciences sociales" (EHESS) (Higher school of social sciences) in Paris and Neuchâtel University in Switzerland, analysing the evolution of the migratory plans of men and women from northern China coming to Paris at the end of the 1990s.

7. Carine Guérassimoff, "La Chine et les nouveaux migrants chinois en Europe, introduction au dossier special," Migrations-Société, Vol. 15, No. 86, March-April 2003, pp. 21-28. 
as being mostly young men from rural areas who are poorly integrated in the local labour market and generally have few qualifications. ${ }^{(8)}$ On the contrary, the migrants from northern China who were interviewed in Paris left their country when they were about 40 years old, and had on average nearly 20 years of professional experience in China. As city dwellers employed by state-owned enterprises and having received secondary or higher education, they considered themselves to have enjoyed a relatively privileged socioeconomics status before leaving. Moreover, this new migration consists mainly of women, who comprise nearly 70 percent of these pioneer migrants and generally make the journey alone. (9) The women in their forties whom we interviewed had all been married in China and were mothers of adolescent children or young adults living in China. However, the majority of them are divorced (80 percent of our sample), whereas most of the men we interviewed are still married in China. Finally, the solitary nature of their departure is a feature of the trajectories of all these migrants, who come from regions with no tradition of international mobility and had no contacts in place who were likely to help them on arrival in their destination country. ${ }^{(10)}$

The specific position of female migrants has long been neglected by researchers, who considered mobility to essentially be a response to economic stimuli (11) and therefore one primarily affecting men, as they were seen as the main income earners of the family. According to this view, which is in keeping with the division of labour on gender grounds, it was assumed that women did not migrate, or if they did, they were considered to do so as passive actors dependent on their husbands or fathers. ${ }^{(12)}$ Questions concerning integration of the second generation in particular have helped shed light on the roles of migrant women, first in the transmission of culture and identity to their children in a family context, then in their participation in the society of the host country, and finally in their access to the job market ${ }^{(13)}$. Taking this perspective has helped introduce the gender dimension as an analytical and relationship-based category in research on mobility, and therefore to consider the way in which representations of the social roles of men and women are culturally and historically constructed. ${ }^{(14)}$ As a principle of differentiation and hierarchisation between the sexes, gender is connected to other power relationships, and structures the functioning of societies, institutions, social relations, and daily practices, ${ }^{(15)}$ these all being aspects that shape the experience of migration. Appreciating the varying representations of male and female roles across countries and over time, the researchers considered whether the mobility of women played a part in changing gender social relations in terms of increasing the independence of women, or conversely reinforced inequalities and traditional roles. ${ }^{(16)}$ The analysis then revealed the diversity of situations between women with regards to the constraints on them and the resources accessible to them, depending on their ethnic origin, age, level of education, etc. Finally, further studies also helped illustrate the "gender-oriented" dimension of migratory, work, and family policies in destination countries. ${ }^{(17)}$

This article is an extension of this structural analysis, but focusing instead on the country of origin. Its aim is to analyse the way in which gender relations in the home country before migration may have influenced migratory decisions. ${ }^{(18)}$ The analysis will focus on the explanations given by the women interviewed in Paris as to why they left and will examine the three main themes that are broached: changes in the structure of the job market, in economic resources, and in family relations. These three thematic levels have often affected men and women differently, and can be used to analyse the economic and social changes taking place at the turn of the century in terms of the gender relations that existed before the departure of this generation of city dwellers in their forties.

\section{Presentation of the field work and methodology}

This article is drawn from a doctoral thesis currently being written, which analyses developments in the migratory projects and trajectories of male and female migrants from northern China living in Paris in highly precarious situations. Making contact with this type of population is complicated; the migrants lack legal status, grasp neither the local language nor social codes, and are often reluctant when it comes to any kind of interaction with "foreigners," i.e., the non-Chinese population. Acceptance is all the more difficult due to the fact that the majority of migrants have difficulty distinguishing the researcher from the local police authorities. Moreover, their legal status, the precarious nature of their

8. In particular see Nathalie Mondain and Alioune Diagne, "Ceux et celles qui restent : réflexions théoriques à partir du cas de l'émigration sénégalaise vers l'Europe," African Migrations Workshop. The Contribution of African Research to Migration Theory, 16-19 November 2010, Dakar, Senegal.

9. Carine Pina-Guerassimoff et al., La circulation des nouveaux migrants..., op. cit.

10. Yun Gao et al., "De la migration au travail. L'exploitation extrême des Chinois-es à Paris," Travail, genre et sociétés, No. 6, 2006, pp. 53-76.

11. For an analysis of the development of migratory theories, in particular see Douglas $\mathrm{S}$. Massey et al., "Theories of International Migration: A Review and Appraisal," Population and Development Review, Vol. 19, No. 3, 1993, pp. 431-466; Thomas Faist, "The crucial meso-level," in T. Hammar et al., International migration, immobility and development: Multidisciplinary perspectives, Oxford/New York, Berg Publishers, 1997.

12. On the invisibilisation of female migrants, among others see: Eleonore Kofman, "Female 'birds of passage' a decade later: Gender and immigration in the European Union," International migration review, Vol. 33, No. 2, 1999, pp. 269-299; Mirjana Morokvasic, "Birds of passage are also women," International migration review, Vol. 18, No. 4 Special, 1984, pp. 886-907, Nasima Moujoud, "Effets de la migration sur le femmes et sur les rapports sociaux de sexe. Au-delà des visions binaires," Les cahiers du CEDREF: Centre d'enseignement, d'études et de recherches pour les études féministes, №. 16, 2008, pp. 57-79.

13. The following articles give an overview of these research papers, which are too numerous to mention: Katharine M. Donato et al., "A Glass Half Full? Gender in Migration Studies," International Migration Review, Special Issue: Gender and Migration Revisited, Vol. 40, No. 2006, pp. 2-26; Sarah J. Mahler, "Engendering Transnational Migration. A Case Study of Salvadorans," American Behavioral Scientist, Vol. 42, No. 4, 1999, pp. 690-719; Janine Dahinden et al., "Edito: Migration et genre en Suisse," Nouvelle Questions Féministes. Revue internationale francophone. Genre et frontières - frontières de genre: migrations, Vol. 26, No. 1, 2007, pp. 4-15; Mirjana Morokvasic et al.," "Gendered Mobilities in an Enlarged Europe," in Sigrid Metz-Göckel et al., Migration and Mobility in an Enlarged Europe: A Gender Perspective, Leverkusen, Barbara Budrich, 2008; Sarah J. Mahler and Patricia R. Pessar, "Gender Matters: Ethnographers Bring Gender from the Periphery toward the Core of Migration Studies," International Migration Review, Vol. 40, No. 1, 2006, pp. 27-63.

14. In particular see Pierrette Hondagneu-Sotelo, "Gender and immigration," in Pierrette HondagneuSotelo (ed.) Gender and US immigration, Berkeley, University of California Press, 2003, pp. 3-19.

15. On this subject see: Kimberlé Williams Crenshaw, "Mapping the Margins: Intersectionality, Identity Politics, and Violence Against Women of Colour," in Martha Albertson Fineman and Rixanne Mykitiuk, The Public Nature of Private Violence, New York, Routeledge, 1994; Joan Scott, "Gender: A useful category of historical analysis," The American Historical Review, Vol. 91, No. 5, 1986, pp. 1053-1075; Candace West and Don Zimmerman, "Doing gender," Gender \& society, Vol. 1, No. 2, 1987, pp. 125-151; Floya Anthias and Nira Yuval-Davis, Racialized boundaries: Race, nation, gender, colour and class and the anti-racist struggle, London and New York, Routledge, 1992.

16. Among others see: Sara J. Mahler and Patricia R. Pessar, "Gendered geographies of power: Analyzing gender across transnational spaces," Identities: Global Studies in Culture and Power, Vol. 7, No. 4, 2001, pp. 441-459; Mirjana Morokvasic, "Migration, Gender, Empowerment," in Ilse Lenz et al., Gender Orders Unbound: Globalisation, Restructuring and Reciprocity, Opladen, Farmington Hills, Barbara Budrich Publishers, 2007; Yen Le Espiritu, "Gender, Migration, and Work. Filipina Health Care Professionals to the United States," Revue européenne des migrations internationales, Vol. 21, No. 1, 2005, pp. 55-75; Brenda Yeoh and Katie Willis, "Constructing masculinities in transnational space: Singapore men on the 'regional beat'," in Peter Jackson et al., Transnational Spaces, London, Routledge, 2004; Sara J. Mahler, "Transnational relationships:The struggles to communicate across borders," Identities Global Studies in Culture and Power, Vol. 7, No. 4, 2001, pp. 583-619.

17. Alexander Trent and Anne-Marie Steid, "Gender and the 'Laws of Migration':A Reconsideration of Nineteenth-Century Patterns," article not published, 2010; Eleonore Kofman and Albert Kraler, Civic Stratification, Gender and Family Migration Policies in Europe, Budapest, 2006; Magalie Gafner and Irène Schmidlin, "Le genre et la législation suisse en matière de migration," Nouvelle Questions Féministes: Revue internationale francophone, Vol. 26, No. 1, 2007, pp. 16-37; Albert Kraler et al., Gender, Generations and the Family in International Migration, Amsterdam, Amsterdam University Press, 2011; Mirjana Morokvasic and Christine Catarino, Mapping of policies affecting female migrants and policy analysis: The French case, FEMIPOL, 2006.

18. We chose here to focus on the perspective of the female migrants; the point of view of the men was mainly used for the purpose of comparison or to illustrate female trajectories. 
professional, economic, social, and emotional lives, and the drop in socioeconomic status experienced as a migrant all hinder building the relationship of trust necessary for ethnographical interviews. My approach therefore began indirectly through community activities in various Franco-Chinese organisations in Paris. This enabled me to meet male and female migrants as a French teacher or interpreter, within the context of social support activities as a mediator for women practicing prostitution on the street, and as co-organiser of a Chinese women's speaking group. The sample was subsequently expanded gradually within the social networks of my contacts, which enabled me to meet people with a great diversity of trajectories, until a "saturation point" was reached and the same life stories began to recur ${ }^{(19)}$. The exchanges, which were initially based on concrete activities, later led to the establishment of a relationship of trust, and it was in this context that in-depth interviews took place in Mandarin in the form of life history and semi-structured interviews with 64 migrants (50 women and 14 men) between 2004 and 2010. (20) Fifteen of these people were interviewed at regular intervals to track the development of their migratory projects. These activities also provided the opportunity for participant observation and informal exchanges in schools, work places, dormitories, places of prostitution, flea markets, etc. This ethnographic approach allowed me to grasp the subjective points of view of the actors.

The male and female migrants interviewed for this research arrived in France between 1998 and 2005, when they were between 35 and 44 years of age. Most of them were originally from the provinces of Liaoning, Shandong, and Hebei, and the Tianjin municipality, but a smaller number were also from cities in Henan and Jilin provinces. Before leaving, 15 of them were unemployed, while the others had kept their jobs in state-owned enterprises, had created their own companies, or had found new but unstable work. All had been married (apart from one woman who had been engaged) and were the parents of at least one child, but 40 of the 50 women were divorced, whereas only two of the 14 men were.

Over the course of the interviews, it became apparent that although the migrants found themselves in highly precarious circumstances in France, ${ }^{(21)}$ most of them had belonged to far from disadvantaged social categories in China. On the contrary, their living conditions there are described as being clearly better than average for China. The female migrants included workers with few qualifications, but also a large number of women in intermediary professions (such as accountants, sales people, team leaders, etc.), as well as managers and businesswomen who had created their own private companies. In spite of the diverse natures of their life trajectories, the male and female interviewees described relatively privileged life courses. As employees of state-owned enterprises, they had had access to a series of benefits placing them in an average socioeconomic category. Their jobs were, in theory, lifetime employment, and although they were paid low salaries, this was offset by a global support system guaranteeing free or subsidised access to housing, health care, education for their children, distribution of material goods, and retirement. Although their incomes before leaving ranged from 400 to 4,000 yuan a month (22), it is the satisfaction level of these migrants that is really telling. Mrs. Yu, whose salary of 400 yuan makes hers one of the more modest incomes in my sample, was responsible for quality control in her factory. She considered herself "about average. We were not very poor, but we did not have any money (saved up)."

At this point in the descriptions, there appears to be little of relevance to explain why these women went abroad; after all, they considered themselves to be well integrated in the job market, society, and at the family level. Furthermore, as ex- state employees, they did not witness any noteworthy discrimination at a professional level until the 1990s, and seem to have had access, at this time, to roughly the same resources as men. The reform period, which was characterised by uncertain policies ${ }^{(23)}$ and modified the structural framework in which their lives were evolving, forced a change in their trajectories. ${ }^{(24)}$ The courses of their lives were marked by a series of more or less pronounced disruptions that brought into play self-image and the interviewed migrants' perceptions of success. The effects of these national policies had an impact first of all at the employment level, then on incomes and finally on the family dimension. As we are now going to see, their migratory project consequently took shape largely in response to a series of "accidents" that occurred in their life trajectories.

\section{Migration, a response to gender discrimination in the job market}

The accounts of our interviewees place particular emphasis on the impact that the economic reforms introduced at the end of the 1970s had on their lives. At first, these were seen on the whole as positive, in that they allowed city dwellers to raise their general living standards. However, in the 1990s, the way they were perceived became more mixed, and the people interviewed have an ambivalent and even critical view of these changes, which they feel put their ability to adapt under excessive stress. Well before they decided to leave for abroad, there were many signs indicating how the lives of some of these women were being turned upside down, as described by Mrs. Wang:

Women aged 35 do not find work easily. My salary was very high. I worked hard from the age of 18 . When I was 36 , our company suddenly went bankrupt, and everything I had collapsed. Our retirement was no longer guaranteed. Our incomes fell to pitiful levels of two or three hundred yuan a month. What can you do with two or three hundred yuan a month in China? [...] In China, you can open a shop and earn lots of money, but one day the government can say that you have to demolish it all, and then you are left with no shop and no money. That happened to a lot of my friends, including in my work unit. [...] There are lots of things over which you have no control, which you cannot make happen. I feel insecure. I do not know what might happen in the future. I'm afraid of being poor. Although I have money at the moment, I do not know how long I will be able to live on it.

What emerges from the life histories of the pre-migratory period of the people interviewed is a dual sentiment of living in an uncertain period char-

19. Jean-Pierre Olivier de Sardan, La rigueur du qualitatif. Les contraintes empiriques de l'interprétation socio-anthropologique, Louvain-la-Neuve, Academia-Bruylant, 2008, p. 365.

20. The names and factual data used to identify the people interviewed have been changed in order to protect their anonymity.

21. See Yun Gao et al., "De la migration au travail...,"op. cit., pp. 53-76; Florence Lévy and Marylène Lieber, "La sexualité comme ressource migratoire : les Chinoises du Nord à Paris," Revue française de sociologie, Vol. 50, No. 4, 2009, pp. 719-746.

22. These differences in salary can be explained by the different positions held, and also by varying living costs between different locations and the differences in private sector and public sector salaries (lower income compensated for by numerous benefits in kind).

23. The reform period that aimed to reduce the role of the state in the economy and introduce capitalist rules to company management is not characterised by a clear political line. It followed power struggles and was mainly characterised by hesitations, checks, and sudden pushes forward. See Jean-Louis Rocca, Sociologie de la Chine, Paris, La Découverte, 2010.

24. Marc Bessin et al., Bifurcations. Les sciences sociales face aux ruptures et à l'événement, Paris, La Découverte, 2009 
acterised by a challenge to past gains and by the knowledge that major and unpredictable changes were just around the corner. The climate of insecurity seems to have manifested itself most on the professional level. Many of the female migrants interviewed in Paris described themselves as xiagang zhigong, i.e., employees and workers of state-owned enterprises suspended temporarily, in principle, and living from small allowances or finding themselves without resources. The withdrawal of the state from direct control of the economy and the introduction of capitalist rules led to a restructuring of China's economic fabric. The state-owned enterprises that formerly employed most of the urban population and managed both production and social organization were considered unprofitable and were forced to restructure in order to adapt to the market. Some turned to new activities, merged, or were privatised, but many also closed between the 1990s and the 2000s. ${ }^{(25)}$ The restructuring of the economy was therefore accompanied by mass urban unemployment estimated at 40-60 million people during the period from 1993 to 2003. ${ }^{(26)}$ The regions in the north and northeast of China, which had until then been renowned for their heavy industries, were among the worst affected. (27) According to Mrs. Yu, when she left at the start of the 2000s, half of the inhabitants of her city, Fushun, were xiagang, and for most of the male and female migrants interviewed, being xiagang was an obvious justification for leaving. This kind of explanation tends towards fitting the migration of city dwellers from northern China into the theoretical constructs of the new economy of migrations, which like neoclassical theories assume that international mobility results from gaps in living conditions and wages between different countries. From this perspective, migrants are seen as informed economic actors who go abroad to optimise their incomes or to reduce economic risk by diversifying the income sources of their households. ${ }^{(28)}$

Although the migrants spoke little about the different trajectories of men and women, scientific literature emphasises that the employment crisis linked to structural reforms in the Chinese economy has not affected the urban population uniformly and has had varying impact on men and women ${ }^{(29)}$ (see the article by Isabelle Attané in this special feature). The first to be made redundant are those considered the least adaptable to the new requirements of productivity and flexible working conditions, (30) i.e., older workers, those with the fewest qualifications, ${ }^{(31)}$ and women. The latter group represents nearly 60 percent of the xiagang even though they make up only 40 percent of the work force. ${ }^{(32)}$ It is no coincidence that all three criteria apply to the profiles of most of the female migrants interviewed in Paris. Generally, the gender criterion partly coincides with the first two indicators, age and qualifications, and reveals that despite claims of gender equality under the Maoist regime, access to educational, political, and financial resources was "gender oriented." (33)

In China, as in many other countries, the women of this generation have, on the whole, completed less schooling than their male counterparts. For this reason, they have often been confined to poorly paid jobs requiring few qualifications in companies in the manufacturing and service industries, the very sectors that lost the most jobs following the restructurings. They were thus ill-equipped to confront this redundancy policy compared with their male counterparts, ${ }^{(34)}$ who often possessed valuable technical knowledge that enabled them to negotiate to keep their positions or find alternative work after being laid off. "In China, what people look at is your level of education, not your experience," explains, Mrs. Li, who feels that the 15 years she spent in the management team of a company with more than 1,000 employees are unlikely to help her find a job. With the increasing rate of unemployment, gender equality in terms of access to the job market has worsened considerably for this generation. ${ }^{(35)}$ The early retirement mechanism has also distanced women from the world of work, given that they were put into early retirement at the age of 45 , five years earlier than men in the same sector. ${ }^{(36)}$

Compounding this is a "gender-oriented" perception of age. Many of the female migrants interviewed who were aged around 40 consider themselves to be old, whereas men of the same generation do not share this view of themselves. As Mrs. Ding explained, age is one of the determining factors explaining why women are excluded from the job market:

Good companies want young people; there is an age limit, and I'm nearly 40 years old. It's difficult to find a good job. In China, [employers] are looking for people between 18 and 30 years old. Sometimes, they want to find people who are not yet married.

Therefore, the trajectories of migrant women show that the combined criteria of age, undervalued qualifications, and gender representations have not only selected which workers are suspended but have also continued to hold them back in their search for stable employment commensurate with their qualifications in a deregulated job market. However, this tendency to define oneself as xiagang needs to be qualified. Most of the interviewed women actually had a job and/or income at the time of their departure.

25. See Antoine Kernen and Jean-Louis Rocca, "La réforme des entreprises publiques en Chine et sa gestion sociale. Le cas de Shenyang et du Liaoning," Les études du CERI, No. 37, January 1998, pp. 1-37.

26. See Jean-Louis Rocca, La condition chinoise. La mise au travail capitaliste à l'âge des réformes (1978-2004), Paris, Karthala, 2006, p. 112.

27. See Antoine Kernen, La Chine vers l'économie de marché. Privatisations à Shenyang, Paris, Karthala, 2004; Antoine Kernen and Jean-Louis Rocca, "La réforme des entreprises publiques en Chine," art. cit.; Jean-Louis Rocca, La condition chinoise..., op. cit.

28. See the presentation of these theories by Douglas Massey et al.,"Theories of International Migration...,"art. cit.

29. Tan Lin et al., Zhongguo funü yanjiu shinian (1995-2005): Huiying "Beijing xingdong gangling" (Review of Chinese women's studies in recent 10 years: Response to the Beijing Platform for Action), Beijing, Shehui kexue wenxian chubanshe, 2005.

30. See Jean-Louis Rocca, La condition chinoise..., op. cit:; Antoine Kernen, La Chine vers l'économie de marché..., op. cit.

31. The qualifications awarded by the Communist regime are now also seen as low-level qualifications because the training from that time favoured political education over technical knowledge.

32. Liu Jieyu, "Gender dynamics and redundancy in urban China," in Günseli Berik et al., Gender, China and the World Trade Organization, New York, Routledge, 2009; Ting Gong, "Women's Unemployment, Re-employment, and Self-employment in China's Economic Restructuring," in Esther Nganling Chow, Transforming gender and development in East Asia, New York, Routledge, 2002; lia Yina, "Funü jiuye zhong zao shouyin xingqishi wenti de chengyin ji duice qianxi" (Causes and solutions to the recessive discrimination against women in employment), Zhonghua nüzi xueyuan Shandong fenyuan xuebao, No. 2, 2004, pp. 20-24; Shi Tong, "Guoyouqiye xiagang nügong bei shehui bianyuanhua lilun yanjiu" (Study of theories of the social marginalisation of xiagang women), in Du Fangqin, Shehuixingbie, Tianjin, Tianjin renmin chubanshe, 2004; Zheng Wang, "Gender, employment and women's resistance," in Elisabeth Perry and Mark Selden, Chinese Society: Change, Conflict and Resistance, London/New York, Routledge, 2003.

33. See Tania Angeloff, "La Chine au travail (1980-2009) : emploi, genre et migrations," Travail, genre et sociétés, No. 1, 2010, pp. 79-102; Zheng Wang, "Gender, employment and women's resistance," op. cit.

34. Jia Yina, "Funü jiuye zhong zao shouyin xingqishi wenti de chengyin ji duice qianxi" (Causes and solution to the recessive discrimination against women in employment), Zhonghua nüzi xueyuan Shandong fenyuan xuebao, No. 2, 2004, pp. 20-24

35. In 1997, national statistics indicated that $80 \%$ of the suspended women were over the age of 35 . See Xin Xu, "Bulu weijian nan ling fengsao, guanyu funü xiagang wenti de sikao" (Moving forward slowly, in a difficult situation. Reflections on the problems of xiagang women), Jiangnan xueyuan xuebao, Vol. 15, No. 3, 2000, pp. 30-33.

36. Jun Liu et al., "Guanyu nannü gongwuyuan tongling tuixiu wenti de taolun" (A discussion on the issues of equal retirement age among male and female civil servants), in Lin Tan et al., Zhongguo funü yanjiu shinian (1995-2005): Huiying "Beijing xingdong gangling" (Review of Chinese women's studies in recent 10 years: response to the Beijing Platform for Action), Beijing, Shehui kexue wenxian chubanshe, 2005 
Only a minority of them had been effectively unemployed for a long period of time. Some had kept their position in a state-owned enterprise, while those who had been laid off had more often than not either created their own companies or found other work, but were not satisfied with their new work and salary conditions. Mrs. Yu, for example, has done several jobs involving "physical labour," and describes them as follows: "Temporary work is very tiring; the salaries are not high; you do not know how long [the boss] will want you to work."

\section{Migrating to escape economic insecurity}

This exclusion from the State-regulated job market has inevitably brought with it a form of economic insecurity. Concern over their ability to maintain a comfortable standard of living for the family unit was the second recurring theme brought up by the female migrants interviewed in Paris. The turn of the century in China was characterised by a sudden increase in urban poverty ${ }^{(37)}$ that had not existed under the Communist regime. In 1999, this poverty is thought to have affected nearly 7 percent of city dwellers, but it was more pronounced in certain provinces where the industrial fabric was structurally more vulnerable to economic restructuring. For example, in Liaoning, the native province of many of the interviewed migrants, poverty increased by nearly 800 percent between 1988 and 1995. (38) Mrs. Dou, who was originally from Tianjin, likewise said, "Our city did not feed us!"

The first people affected are those who, having lost their job, find their unemployment insurance discontinued. In principle, Chinese law claims to maintain the income level and social security of a person who loses his job. In reality, however, some people find themselves destitute, their only income coming from allowances that are too low to maintain their living standards, or indeed they find themselves with nothing, because bankrupted companies do not always have the legally-mandated social security measures in place. Having been ordered "back home" without compensation, Mrs. Yu and her colleagues were able, after several months of protesting to the authorities, to obtain payment for their salary arrears and compensation for breach of contract equal to a month's salary for every year worked. She therefore received 8,000 yuan for the 21 years she had spent in her factory. People who are suspended from their jobs therefore suffer a major drop in income, and the likelihood of xiagang families finding themselves in poverty is consequently three to six times higher than that of other urban households. (39) These situations, which more often affect women, also have different effects on men and women due to of the different family and social expectations placed on them.

The feeling of insecurity expressed by the female migrants interviewed also stems from the fact that the state's social security system is being called into question? ${ }^{(40)}$ due to changes in the economic model. Therefore, while work units were previously responsible for most of the needs of their employees, the feeling of no longer having any social safety net and being able to rely only on oneself has left a deep impression on people, as Mrs. Ding explains:

There is no social system in China. If you work, you have your salary; if you do not work, you do not receive any unemployment benefits. There are no family allowances, and education fees are very expensive. And if you fall ill, a day in hospital costs a month's salary, if not more.
The family is at the heart of two central concerns often voiced in the stories of female migrants, and is related to the cost of healthcare ${ }^{(41)}$ and education. Access to these services, which was previously almost free, now seems to be threatened by market principles, because the two now command exorbitant prices that often stretch the financial means of the population. ${ }^{(42)}$ Therefore, as Mrs. Dou explains: "Everyone has to pay for their own healthcare. If you do not have the money, the hospital will not let you in, and you will die outside. No one will look after you. [...] The deposit [for admission to the hospital] is 5,000 yuan." "The tuition at good universities is very high. Most families can't afford it," explains Mrs. Ding, who gives the example of a good university in Shenzhen where "one year's tuition costs 20,000 yuan, while the salary of an average worker is 10,000 yuan a year; before even considering the cost of food and drink, how are you supposed to find this money? You have to save up."With increasing competition on the job market, young people also face unemployment, and university qualifications, especially from reputable institutions, are a deciding factor in their search for a good job. Parents thus feel it is their duty to provide their child with access to a university, even if this entails running up debt.

"Both child and parents need support at home. If the parents fall ill, it's all over. [The equivalent of] one month's living costs go up in smoke," explains Mrs. Dou. Having to simultaneously assume responsibility for parents who are ageing and therefore more likely to fall ill, and for enrolling their only child in higher education, puts the generation in their forties in a particularly precarious situation. Assuming what are seen as essential duties to their dependents confronts them with an unprecedented need for money. Indeed, the men and women interviewed in France find it difficult to contemplate not allowing their only child to continue schooling or failing to provide their parents with health care. To do so would call into question the meaning they attribute to their social roles in terms of parenthood and filial duty, resulting in a strong sense of guilt. These social roles are expressed in imperious terms, as Mrs. Zeng describes: "In China, it is not like it is in France; parents sacrifice themselves for their children."

The wish to "fulfil one's responsibilities" is therefore often a decisive factor in the decision to migrate, for both men and women. As Mrs. Yu explains:

I could not solve the most fundamental problems, so what's the point of talking about the rest? [If I had remained in China] my child would only have been able to study up to A-level standard, and would then

37. See Joseph Chai, "Consumption and living standards in China," The China Quarterly, No. 131, 1992, pp. 721-749; Antoine Kernen, "Shenyang apprend à gérer ses pauvres," China Perspectives, No. 11, May-June 1997, pp. 17-21; Li Shi and Zuo Tenghong, Jingji zhuanxing de daijia: Zhongguo chengshi shiye, pinkun, shouru chaju jingyan fenxi (The price of economic transition: Analysis of the differences in income, poverty and unemployment in Chinese cities), Beijing, Zhongguo caizheng jingji chubanshe, 2004.

38. Xue Jinjun, "Zhongguo chengshi shiye, pinkun he shouru fenpei chaju" (Differences in income, poverty and unemployment in urban China), in Li Shi and Zuo Tenghong, Jingji zhuanxing de daijia..., op. cit.

39. Li Shi, "20 shiji 90 niandai mo Zhongguo chengshi pinkun de ehua jiqi yuanyin" (The causes of increasing urban poverty at the end of the 1990s), in Li Shi and Zuo Tenghong, Jingji zhuan xing de daijia..., op. cit.

40. See Jean-Louis Rocca, La condition chinoise..., op. cit:; Antoine Kernen and Jean-Louis Rocca, "La réforme des entreprises publiques en Chine," art. cit.

41. Yuanli Liu and William Hsiao, "Les soins de santé en Chine: I'histoire de deux époques," in Isabelle Attané (ed.), La Chine au seuil du XXIe siècle : questions de population, questions de société, Paris, INED, 2002.

42. Marianne Bastid-Bruguière, "Les offres de formation du système scolaire chinois," Perspectives chinoises, No. 65, 2001, pp. 17-27; Gail Henderson, "Increased Inequality in Health Care," in Deborah Davis and Ezra Vogel, Chinese society on the eve of Tiananmen: The impact of reform, Cambridge, Harvard University Council on East Asian, 1990; Yuanli Liu and William Hsiao, op. cit;; Christine Nguyen Tri, "La privatisation de l'éducation en Chine," Perspectives chinoises, No. 65, 2001, pp. 28-35; Henderson, op. cit. 
only have been able to find a very precarious position on the job market. That's all. My child would have had no future. [...] Now, financially, I can afford to send my daughter to university. That was the biggest problem facing me and I overcame it. It's my greatest success!

Another worry relates to the purchase of housing in China. Soaring property prices, which had long been subsidised by the work units, are paradigmatic of these transformations. Boosted by the state, a private housing market has developed, quickly becoming very costly and speculative. This situation is a subject of concern to the people interviewed, who face the need to buy an apartment, either out of necessity following demolition of their old quarters in urban redevelopment, or in order to meet the expectations of their middle-class social group, which looks down on old buildings. Moreover, many associate this desire for new housing with concern for the future of their child, and actually think they have a duty to comply with new practices, in particular by buying their son a new apartment to improve his marriage prospects. Even though her son had not yet found a fiancée, it was this worry that led to the departure of Mrs. Chu: "I had to be able to buy an apartment for my son in order for him to be able to get married."

Finally, changes in lifestyles and the rapid development of a consumer society ${ }^{(43)}$ have led to the emergence of new needs in terms of consumer and leisure goods. Economic capacity has been a determining factor when it comes to evaluating the success of an individual or family, to the detriment of the statutory elements given priority in the old system. The social pressure is very great, because for some of the women I spoke to, opportunities to consume became a test of their position in the social hierarchy. For example, when her income dropped, Mrs. Chu struggled to maintain her rank. "Not everyone can live at the same level. Some of us have to go out, go to the restaurant, get together with old classmates. Everyone pays in turn, and you can't get away with never paying." These new desires, which are seen as legitimate, become especially delicate to manage when they come from an only child, because once more they bring into play the ability of parents to fulfil their role and guarantee the happiness of their offspring.

These new enticements foster feelings of frustration when it comes to actual living standards. The stories of the male and female migrants therefore reveal a sense of relative deprivation ${ }^{(44)}$, with certain categories of the urban population perceiving that their own quality of life is not improving as quickly as that of other groups with which they compare themselves. They interpret this discrepancy as a sign of impoverishment, as underlined by Mrs. Ding: "In China, although the economy has grown a lot, living standards have not improved much from the point of view of families." It is true that since the Maoist era, which had a reputation for operating on a relatively egalitarian basis, inequalities have increased greatly ${ }^{(45)}$, to the point that at the start of the 2000 s, 20 percent of the population possessed nearly half of the country's total resources. ${ }^{(46)}$ The dissatisfaction generated by this situation, which has been described as a social divide, ${ }^{(47)}$ emerged in the meetings held in Paris, where interviewees denounce a society perceived as unfair in its redistribution of wealth. In fact, the entire social stratification of cities was reconfigured in the 1980s. ${ }^{(48)}$ Workers and employees of state-owned enterprises, who previously enjoyed very privileged position, suffered a drop in status compared with new social groups, in particular private entrepreneurs, who displayed their success through rapid enrichment and ostentatious spending.

Despite a general improvement in living conditions, confusion shows through in accounts of the professional opportunities available in China and the meagre salaries on offer. The imbalance between the speed at which needs developed compared to salaries, especially in the public sector, appears to have been particularly demotivating, as emphasised by Mrs. Ding, who states, "Even if I had found a good job in China, I really would not have wanted to do it, because the wages were really too low." The salaries on offer abroad look much more attractive in comparison.

\section{An increasingly insecure family situation and newly divorced status: A first step towards a move abroad}

These professional and economic difficulties also interact with relationships within the family unit, which is the third subject of major concern mentioned by the migrants. Tensions within couples, in particular, are behind a significant rise in divorce rates for city dwellers in their forties. The number of divorces has tripled in the 20 years since the implementation of reform and opening. ${ }^{(49)}$ Although new marriage laws introduced in 1981 and 2001 have contributed to this trend by facilitating the procedures, ${ }^{(50)}$ these legal changes are not the only cause. Of the female migrants interviewed in Paris, the proportion of divorcees was well above the national average, at a rate of 80 percent ( 40 out of 50 interviewees), while the men remained married (apart from two out of 14). These rates, coupled with the short time, in many cases, between the divorce judgement and the decision to leave for abroad, give rise to questions about the links between marital status and migration. The migrants themselves portrayed these two situations in terms of a cause/effect relationship. According to Mrs. Yu:

Out of every ten women who have left for abroad, eight have done so because they were not happy in their home life. [...] In very few cases have people left purely out of curiosity when the relationship with the husband was good and everything was fine with the family.

However, as Mrs. Yu explains:

You only get divorced when there are big problems and it is impossible to go on. For example, if the man has a mistress or the wife a lover, it is impossible not to divorce; if there is a conflict between mother-in-law and daughter-in-law, it's less frequent, because ultimately that is not such a big problem. In China, it's enough for [the husband] to be able to earn money and support the family. Every-

43. Deborah Davis (ed.), The consumer revolution in urban China, Berkeley, University of California Press, 2000.

44. Stark and Bloom, "The new economics of labor migration," American Economic Review, Vol. 75, No. 2, 1985, pp. 173-178.

45. Feng Wang, Boundaries and Categories: Rising Inequality in Post-Socialist Urban China, Stanford, Stanford University Press, 2008.

46. Deborah Davis, "Urban consumer culture," The China Quarterly, No. 183, 2005, pp. 692-709.

47. Sun Liping, "Women zai kaishi miandui yige duanlie de shehui?" (Are we facing a social divide?), 2003, www.sociology.cass.cn/pws/sunliping/grwj_sunliping/t20031008_1192.htm (consulted on 10 October 2012).

48. Jean-Louis Rocca, Sociologie de la Chine (Sociology of China), Paris, La Découverte, 2010.

49. Qingbin Wang, "China's Divorce Trends in the Transition Toward a Market Economy," Journal of Divorce \& Remarriage, Vol. 35, No. 1-2, 2001, pp. 173-189.

50. It is now possible to end a marriage in the absence of major wrongdoing via a procedure similar to mutual consent, in particular by citing a lack of reciprocal affection. Conjugal violence and adultery are also reasons that can give rise to punishment and divorce. These legal changes make it possible for couples who were unable to end a marriage under previous jurisdictions to do so now. 
thing else is just small issues beneath mention; they don't matter. All I need to be satisfied is to earn money, support my family, and spend my days [living a simple life].

Despite this principled opposition, it was more often than not the women we interviewed who initiated the divorce. They spoke at length about this choice, ${ }^{(51)}$ which amounted for some of them to "no longer having a family."

For these female migrants, the increase in the number of divorces is one of the consequences of the reforms, which have led to a change in attitudes and an individualisation of behaviour that they see as reflecting a drop in morality. It appears that the balance long maintained in couples of this generation was upset by newly expressed expectations of the partner regarding personal fulfilment and happiness, which then led to disappointment and tensions. ${ }^{(52)}$ Based on observations made in a village in north-east China, the anthropologist Yan Yunxiang observed similar developments and the emergence of a new family ideal: "The modernity of the contemporary family lies in the rising importance of individual desires, emotions and agencies in family life, on the one hand, and the centrality of the individual in family relations, on the other hand." (53) An analysis of the reasons that pushed female migrants to ask for a divorce shows that the gender roles within couples were put under pressure in the decades leading up to their departure. It seems that transformations in the relationship with money, which is taking an increasingly important place in interpersonal relations, have accentuated disagreements between partners. First and foremost, the interviewed women often complained about the behaviour of their husbands, who no longer matched up to what the women believed they had the right to expect of them. They are accused of "failing to assume their responsibilities" as head of the family, "not taking charge of the family," and "not bringing money into the home." After decades of talk about gender equality, and even though all my female contacts had taken part in economic activity in China before their divorce, these disappointed expectations show that men were seen as the main and essential economic providers for the family. Indeed, the majority of the interviewed women assess their contribution to family life almost exclusively in terms of their financial capacity. Mrs. Hou was in despair about her husband, a passionate gambler: "He has no love for his wife, parents, brothers, or sisters. The only person he cares about is himself. After all these years spent together, he never brought any money home. [...] He doesn't look after his sons. He is selfish."

In these circumstances, being an unemployed man brings even more dishonour, especially if your wife continues to work. Some men refuse to take unskilled jobs, like the husband of Mrs. Li, who was a construction engineer but now prefers to "stay home." Mrs. Zhang, who worked in the clothing industry, explains the situation as follows:

The situation is now reversed. [...] Today, it is the man who stays home, makes the meals and serves his wife; women are the ones who go out and earn the money. [...] In the home, the woman has the final word because the man does not earn much.

The link between financial capacity and power relations within the household is clearly apparent in the accounts of the female migrants. The interviewed women show obvious contempt for husbands who fail to assume their economic role. Mrs. Li compares her husband to a cleaning lady. Mr. Guo, for example, whose conjugal relations soured after he lost his job, ex- plains that his wife "thought she was stronger than me. She despised me [and criticised me] for being a man who could not support his wife." What is therefore taking place in these cases is a veritable symbolic reversal in the hierarchy, because it is now the woman who occupies the dominant position. The husbands are described by their wives as "not being man enough" or being "incompetent." Quite apart from their financial capacity, their overall masculinity is also called into question and undermined by the economic transformations. Moreover, the interviews we conducted with male migrants show that they share these dominant representations of gender roles. They often emphasise the fact that they have left "in order to support their family" and explain that they send most of their salary "home." They therefore chose to migrate in order to conform to this social role, which has taken on an economic aspect. It can therefore be seen that in some families, when the husband becomes unemployed, the economic and family support roles that would traditionally fall to him are carried out by his wife. Women find themselves at the head of the family, either because they have succeeded in keeping their jobs or because they have accepted new, lower status jobs. These permutations in social roles often weaken relations within couples.

Secondly, in households that are not necessarily experiencing economic difficulties, another major reason given by female migrants for their divorce is the discovery that the husband is having extra-marital relations. "Things have changed. China is truly chaotic. In the past, only the rich had mistresses, but now even the poor have them," explained Mrs. Ding. Adultery appears to be closely linked to social and economic success. Therefore, financial affluence and flaunted sexuality would appear to go hand-in-hand in the construction of a dominant model of middle- and upper-class masculinity. Two related phenomena are touched upon. On the one hand, men considered to be rich are courted by young women, and on the other hand, it now appears to be positively regarded, especially in business circles, for men to display their social and economic success through ostentatious spending and by appearing in public in the company of young women. ${ }^{(54)}$ This is how Mrs. Xu explained the attitude of her husband: "In China, it is really common for managers to have a person [a mistress]. It's fair to say that in China, if the [economic] conditions [of the man] are not good, no one will go with him."

At the same time, implicitly, husbands are expressing new expectations of feminine behaviour. For example, Mrs. Tai, a hyperactive businesswoman, explained that her husband backed up his request for a divorce by complaining about her "excessively masculine" behaviour and the fact that she "only thought of work." Indeed, the generation of city-dwelling women succeeding that of the Red Guards does not match the representations of femininity that characterise society under reform. ${ }^{(55)}$ Yet some men in this generation are now turning to younger women who openly present an

51. A contrario, this subject was not often mentioned by the men, most of whom are still married.

52. These changing perceptions are accompanied by legal changes, because the law tends to recognise the search for individual happiness, whether psychological, emotional or sexual, as a basis of marriage, and it makes divorce possible if one of these points is not fulfilled. See the articles "Mariage," (Marriage) by Karine Guérin, and "Sexualité," (Sexuality) by Évelyne Micollier, in Thierry Sanjuan (dir.), Dictionnaire de la Chine contemporaine, Paris, Armand Colin.

53. Yunxiang Yan, The individualization of Chinese society, Oxford, Berg, 2009, pp. xxiii-xxiv.

54. In particular see the work of Zheng Tiantian about the new norms of masculinity in company environments, as displayed in interactions between male clients and female hostesses in hostess bars. Tiantian Zheng, "Female subjugation and political resistance: From literati to entrepreneurial masculinity in the globalizing era of postsocialist China," Gender, Place \& Culture, Vol. 1, No. 18, 2012, pp. 19

55. See Isabelle Attané, Une Chine sans femmes ?, Paris, Perrin, 2005, pp. 113. 
image of women as being passive, flirtatious, and physically ultra-feminine, making strategic use of their submission to men. ${ }^{(56)}$ Finally, the interviewed women explain that some aspects of married life that had long been tolerated are now causes for divorce. These include disagreements between husband and wife, conjugal violence, and even "intrusion by the mother-in-law" into the couple's intimate space. The accounts of migrant women therefore show that the representations of gender roles and power relations within couples are being renegotiated at the time that these men or women are deciding to leave their country.

The stories of the female migrants emphasise how their status as divorcees, and in particular as female divorcees taking sole charge of the family, has put them in an unprecedented situation that greatly undermines them. ${ }^{(57)}$ However, this theme was almost never brought up unprompted by the male migrants, most of whom were still part of a couple. First and foremost, it appears to be society's view ${ }^{(58)}$ that is particularly difficult to manage. Divorced status is calling into question the distribution of traditional social roles between men and women in a society where celibacy was once virtually unknown; according to the female migrants, it is still an exception in the over-40s generation. Having divorced very early in 1986, Mrs. Hong recounted how her new status made her famous in her factory, and how workers would suddenly appear in her office just to stare at her. Women are often shouldered with responsibility for the break-up, because they are expected to be able to endure everything in order to maintain the family unit, as highlighted by the proverb: "Marry a chicken, follow the chicken, marry a dog, follow the dog" (Jiaji sui ji, jiagou sui gou).

For some of the older women interviewed, divorce is the equivalent of a loss of face. "In China, if you are not married but you have a child, people will die of laughter, they will not respect you. You are not someone to be taken seriously... It is really bad," explains Mrs. Yu. Dishonour appears to be directed not only towards the couple in question but also stains the reputations of their parents and children. Furthermore, they claim the consequences affect all levels of socialisation, to the point where even jobs are threatened. As Mrs. Li explains, "In my profession, getting divorced was not allowed. [...] My circle of life was very narrow. If all those people criticised me, I'd drown myself. In the eyes of other people, I would never again be able to hold my head high." She thought that if her divorce were made public, she would lose the authority needed to continue working as a trade union official. Indeed, in order to avoid the very strong social stigma, some couples decide to hide the fact that they have split up. This is the case, for example, with Mrs. Shao. In order to maintain an illusion of family unity, she continued to live with her husband for three years before finally leaving quietly for abroad. Her son was only told of the split a few years later. The accounts reveal that this disgrace is also internalised by some female migrants, who cannot forgive themselves for what they consider a failure. In addition to feelings of failure in their role as wives, these women also express guilt towards their child, for whom divorce is often seen as a major destabilising factor. ${ }^{\left({ }^{(5)}\right)}$ In China, as elsewhere, divorce is often accompanied by a drop in economic status ${ }^{(60)}$. Single-parent families cannot fall back on the strategies of working class couples who reach a relatively comfortable standard of living by combining two incomes, one of which covers day-today living expenses while the other is saved for major expenditures and to cover unforeseen circumstances. In this configuration, single-parent families can potentially find themselves more vulnerable to poverty. ${ }^{(61)}$ Unequal incomes between the sexes aggravate this phenomenon because women typically receive lower salaries than men. Also, according to the female migrants, alimony is often not paid or is only partially paid, and the parent who has not won custody breaks his or her links with the child.

The life histories collected also show that losing the family home was another consequence some women have to adjust to after divorcing. Owing to a lack of means, some couples had to continue living together in a marital apartment divided into two territories following their divorce. It should also be noted that some female migrants preferred the option of giving up all their rights and property in order to obtain a swift divorce judgement rather than having to enter into difficult negotiations with their husband. "The only way to get the divorce was to give it all to him. If I give you everything, it's over," says Mrs. Yu. These economic transactions actually equate to "buying" the agreement of the recalcitrant partner. Opting for this strategy was undoubtedly easier for people intending to leave for abroad. For this reason, a number of the interviewed women said they no longer possessed anything in China, including a home.

On the other hand, most of them had fought to win custody of their child. By this decision they were able to contradict the commonly-held prejudice that divorced women are bad mothers who place no importance in the family, and instead underlined their attachment to their parental role, giving absolute priority to the child. However, it amounts to a dubious victory because it takes them even further from the standard family pattern. "Deliberately" becoming the head of a single-parent family, unlike becoming a widow, was not something to be undertaken lightly in their social group at the end of the 1990s, and for some it amounted to an infringement of social roles. Also, in most cases in our interviews, these single-parent households consisting of a mother and child are integrated into the maternal branch of the family, and the extended family framework takes over from the nuclear family. The parental roles are thus shared with grandparents, uncles, and aunts.

Having become the sole head of their families, these women often have to assume all the costs of raising their child. For them, it is simply not an option for divorce, already a social negative, to be accompanied by a drop in economic status for the child. The need to financially secure the child's material well-bring and future is another reason often given by female migrants to explain why they left for abroad. Explaining migration as a sacrifice made for the family serves to curtail criticism and frames mobility in the context of positive and highly consensual norms. Therefore, this aim of ensuring a financially comfortable life prevails, from their point of view, over their daily presence in their child's life. This approach gives rise to a definition of the maternal role that favours the function of the economic provider over that of the provider of care. ${ }^{(62)}$ The child is, in most cases, temporarily

56. See Zheng Wang, "Gender, employment and women's resistance," op. cit;; Tiantian Zheng, "From peasant women to bar hostesses: Gender and modernity in post-Mao Dalian," in Arianne Gaetano and Tamara Jacka, On the Move: Women in Rural-to-Urban Migration in Contemporary China, New York, Colombia University Press, 2004.

57. Chau-Kiu Cheung and Elaine Suk-ching Liu, "Impacts of Social Pressure and Social Support on Distress Among Single Parents in China," Journal of Divorce \& Remarriage, Vol. 26, No. 3-4, 1997, pp. 65-82.

58. Xu Anqi, Jiehai Zhang and Yan Xia, "Impacts of Parents' Divorce on Chinese Children," Marriage \& Family Review, Vol. 42, No. 3, 2008, pp. 91-119.

59. Xu Anqi, Jiehai Zhang, and Yan Xia, "Impacts of Parents' Divorce...," op. cit.

60. In particular see Bernadette Bawin-Legros (ed.), Familles, mode d'emploi, Bruxelles, De Boeck \& Larcier, 1999, p. 62.

61. See Olivier David and Raymonde Séchet, "Les familles monoparentales, des familles comme les autres mais des parents plus vulnérables," Colloque "Femmes et insertion professionnelle," Le Mans, 13 and 14 May 2004

62. A similar phenomenon concerning the expansion of the definition of what is expected of a "good mother" has been analysed in the case of Latin American migrants living in the United States and developing a new model of transnational motherhood. See Pierrette Hondagneu-Sotelo and Ernestine Avila, "I'm Here, but I'm There: The Meanings of Latina Transnational Motherhood," Gender and Society, Vol. 11, No. 5, 1997, pp. 548-571. 
looked after by a grandmother or in some cases by an aunt. He or she then leaves for college, moving onto the campus. For the men in my sampling, concerns relating to their parenthood are expressed in far less critical terms, and are above all described from the perspective of sending money home to their wives, who have remained in China to manage the daily life, education, and future plans of their offspring.

The status of being a single divorced woman taking sole charge of her family is therefore an additional handicap that accentuates professional and economic difficulties that existed before the divorce. Yet my interviewees feel they have little chance of escaping this unappreciated category and remarrying, because the fact that they have a child to look after is combined with unfavourable age-related prejudices. "Who is interested in you when you're 40?" asked Mrs. Yang. This social perspective clearly does not apply in the same way to men, because a certain number of their ex-husbands have remarried.

\section{Conclusion}

The people who turn to migration are faced with a series of life course accidents (redundancy, drop in income, unemployed husband or wife, marital conflicts) that threaten their professional future, their standard of living, or their position in the social hierarchy. For women, divorce tends to have a multiplying effect on previous obstacles. Therefore, some of these future female migrants find themselves, according to the typology of Robert Castel, ${ }^{(63)}$ in a zone of "social vulnerability" that could potentially lead to a process of disaffiliation, i.e., a break in the societal link resulting in marginalisation and social exclusion. Indeed, the two major areas of social integration are put to the test: on the one hand, work, which generates not only a stable income but also a certain social utility, thus providing a place in society; on the other hand, primary and secondary socialisation networks, which allow relational integration and access to forms of social support. However, the economic and social transformations have had different effects on city-dwelling middle-class men and women in their forties. Gender representations have put direct economic pressure on the former, because money has become the main indicator of social success. In such conditions, for men who have been made redundant and have been unable to find a stable new job, it has become more and more difficult not to assume the role of main economic provider of the family on the one hand, and not to not publicly display one's financial affluence on the other.

The constraints imposed by gender norms break down differently for women, especially if they are divorced. They have had to face up to professional and economic tensions and social stigmatisation. This is partly a result of their new status as divorced women having to assume sole charge of a single-parent family. This position, which is generally not looked upon kindly and forces them to apply themselves to masculine areas, represents a challenge; it is a triggering factor in their decision to leave their country. Male and female migrants do share similar perceptions, however. They feel they did not have enough resources in place to assume their social obligations and saw migrating as a new and alternative way of conforming to the expectations weighing on them. It can therefore be seen that the changing social norms and gender roles that have influenced middle-class city dwellers in their forties in northern China have had an impact beyond the borders of the country and have greatly contributed to the gender configuration of this migratory flow heading for Europe. These developments in gender norms and relations also explain why the migratory projects of men and women differ. The main aim of the former, who are still married, is to send money back to their families in China; the latter, most of whom are divorced, wish to provide a better standard of living for their children, to escape the stigmatised status of the "divorced woman," and (why not?) to build a new life for themselves once in France.

\section{Translated by Will Thornely.}

IFlorence Lévy is a PhD student at the Centre d'études de la Chine moderne et contemporaine (CECMC) (Research centre on modern and contemporary China), École des hautes études en sciences sociales (EHESS) and Neuchâtel University.

Centre d'Études de la Chine Moderne et Contemporaine (CECMC), EHESS, 190-198, avenue de France, 75013 Paris, France (florencelevy@yahoo.fr). 